\title{
ЕКОНОМІЧНА ТА ЕНЕРГЕТИЧНА ЕФЕКТИВНІСТЬ ВИРОЩУВАННЯ НАСІННЯ ГОРОХУ ПОСІВНОГО ЗАЛЕЖНО ВІД СОРТОВОГО СКЛАДУ, ІНОКУЛЯНТІВ ТА ЗАХИСТУ РОСЛИН
}

\author{
ВОЖЕГОВА Р.А. - доктор сільськогосподарських наук, професор, \\ академік Національної академії аграрних наук України \\ https://orcid.org/0000-0002-3895-5633 \\ Інститут зрошуваного землеробства НААН \\ СОРОкУнСькИЙ С.С. - аспірант \\ https://orcid.org/0000-0001-8762-012X \\ Інститут зрошуваного землеробства НАAН
}

\begin{abstract}
Постановка проблеми. Проблема підвищення урожайності гороху $є$ важливою для народного господарства України. Не менш актуальним є завдання підвищення економічної ефрективності його виробництва, оскільки в останні роки цій культурі мало приділялось уваги. Слід зазначити, що сучасна технологія вирощування гороху, і насамперед удосконалена, може забезпечити високий рівень продуктивності, передбачає ефективне використання мінеральних добрив, засобів захисту посівів від бур'янів, шкідників та хвороб, проте ці технології недостатньо адаптовані до кліматичних змін і стрес-фракторів. Така ситуація потребує розробки й упровадження нових підходів, особливо з точки зору пристосування окремих агротехнологічних чинників до певних погодних умов [1, 2].
\end{abstract}

Аналіз останніх досліджень і публікацій. Основним завданням агропромислового комплексу України $€$ фрормування ринкових механізмів, які здатні бути стимулюючим чинником економічного прогресу, змушували суб'єкти господарської діяльності відновлювати й у подальшому нарощувати обсяги сільськогосподарського виробництва, спонукав освоювати нові технології виробництва продукції і відмовлятися від застарілих, боротися за зниження собівартості продукції і підвищення рентабельності. У сучасних умовах ведення сільського господарства важливою вимогою до елементів технології, які розробляються та впроваджуються у виробництво, в тому числі і для гороху, є зниження собівартості одиниці продукції, зменшення енергетичних витрат, і як результат - підвищення прибутку [4].

Матеріал і методи досліджень. Метою досліджень було визначити економічну та енергетичну ефективність вирощування насіння гороху посівного залежно від сортового складу, інокулянтів та захисту рослин у неполивних умовах Південного Степу України.

Дослідження проводились упродовж 2018-2020 років на дослідному полі Інституту зрошуваного землеробства НААН. Польові досліди закладалися методом розщеплених ділянок у чотириразовій повторності згідно методики дослідної справи в агрономії [5]. Економічну та енергетичну ефективність встановлювали згідно спеціальних методик [6, 7]. Вартість агроресурсів, технічних засобів, матеріалів тощо для здійснення економічних розрахунків прийнята на період 3 кварталу
2020 року, ціна 1 тонни насіння гороху в цей період склала 16 тис. грн. Схема досліду представлено в таблицях 1, 2. Агротехніка вирощування насіння гороху посівного в дослідах була загальновизнаною для умов півдня України.

Результати досліджень. Вартість валової продукції при вирощуванні насіння гороху посівного залежно від сортового складу коливалася, в середньому, в діапазоні від 27,1 тис. грн/га (сорт Оплот) до 35,0 тис. грн/га (сорт Царевич). Даний показник за вирощування сортів Дарунок Степу (33,3 тис. грн/га), Отаман (30,2 тис. грн/ га) і Світ (28,1 тис. грн/га) поступався сортові Царевич. Якщо порівнювати у відсотках, перевага останнього перед Оплотом, з точки зору вартості валової продукції, дорівнювала 29,2\%. Для інших сортів це значення було меншим з коливаннями в межах від 5,1 до 24,6\%.

Застосування інокулянтів (фактор В) забезпечило максимальну ефективність у варіанті з сортом Царевич, оскільки при застосуванні Біогелю вартість валової продукції збільшилася до 37,1 тис. грн/га. У контрольному варіанті без інокулянтів (обробка водою) одержали грошове надходження на рівні 32,1 тис. грн/га, що на 15,6\% менше за перший показник. Проте цей показник був вищім, ніж, за вирощування сортів Світ і Оплот із застосуванням інокулянтів.

Результати дослідження свідчать, що препарат АКМ був менш ефективний, ніж Біогель. Так, за вирощування сорту Дарунок Степу вартість валової продукції порівняно з варіантом без обробки інокулянтами склала 30,6 тис. грн/га, тобто зросла на 10,8\%, порівняно на $15,7 \%$ - у варіанті застосування Біогелю. Менш продуктивні сорти (Світ, Оплот) також краще реагували на обробку насіння інокулянтом Біогель, але ця перевагу мала низькі значення.

Захист рослин (фактор С), представлений у дослідженні біологічним і хімічним захистом, позитивно позначився на величині вартості валової продукції. Якщо порівнювати середнє значення, даний показник збільшився з 25,1 тис. (обробка водою) до 34,7 тис. грн/га, або на $38,2 \%$, засвідчивши перевагу хімічного методу захисту рослин.

Виробничі витрати на вирощування насіння гороху посівного слабко відрізнилися залежності від сортового складу. Найдешевшим виявилося вирощування сортів, що внаслідок низької урожайності формували найнижчу 
вартість валової продукції, а саме - Оплот (12,8 тис. грн/га) і Світ (12,9 тис. грн/га). Значимо, що вирощування сортів Отаман (13,0 тис. грн/га), Дарунок Степу $(13,1)$ тис. грн/га) і Царевич $(13,2$ тис. грн/га).

Використання інокулянтів, які досліджували по фрактору B, не призвело до зростання витрат. За варіантами цей показник коливався від 12,8 тис. грн/га (сорт Світ, який вирощували з інокуляцією АКМ) до 13,3 тис. грн/га (сорт Царевич з обробкою насіння Біогелем). Цікаво, що в умовах відмови від інокулянтів (контроль) витрати, в середньому по фактору, лишалися такими самими, як і у варіантах з обробкою насівання препаратами АКМ і Біогель.

Хімічний захист рослин показав найбільший рівень виробничих витрат при вирощуванні сортів гороху в умовах Південного Степу України. Так, у середньому по фактору, цей варіант фрактору С потребував зростання до максимального рівня виробничих витрат - до 13,7 тис. грн/ га, що на 11,32\% більше, ніж у контрольному варіанті.

Собівартість вирощування 1 тони насіння гороху насамперед залежала від сортового складу. Найдорожчими виявилося вирощування сортів Оплот (7,7 тис. грн/т) та Світ (7,5 тис. грн/т). При цьому найменша собівартість була за вирощування насіння сортів Царевич (6,1 тис. грн/т) і Дарунок Степу (6,4 тис. грн/т). Якщо порівнювати рівні собівартості, то різниця між крайовими значеннями цього показника склала $26,2 \%$.

Проведення інокуляції насіння біопрепаратами сприяло зменшенню собівартість порівняно з контрольним варіантом за вирощування всіх досліджуваних соритів. При цьому препарат Біогель виявився більш ефективнішим, ніж препарат АКМ. Слід відзначити, що собівартість гороху сорту Дарунок Степу завдяки застосуванню Біогелю знизилася на 13,1\%, а завдяки здійснення інокуляції препаратом АКМ - на 7,3\%.

Відмова від захисту рослин стосовно фрактору С призвела до суттєвого підвищення собівартості вирощування насіння гороху. У середньому по фактору цей показник дорівнював у контрольному варіанті (без захи- сту рослин) 7,9 тис. грн за одну тонну насіння. Хімічний захист рослин сприяв зменшенню собівартості до 6,4 тис. грн/т, або на 23,4\%, підтвердивши його високу есрективність.

Умовний чистий прибуток $є$ одним з найважливіших показників ефективності насінництва сільськогосподарських культур, у тому числі й гороху (табл. 1). В наших польових дослідах цей показник суттєво змінювався під впливом досліджуваних фракторів і варіантів. Так, умовний чистий прибуток при вирощуванні насіння гороху посівного суттєво залежав від сортового складу (фактор А). Визначено, що за вирощування сорту гороху Царевич, у середньому, вдалося отримати з одного гектару посівної площі 21,8 тис. грн.

На ділянках польового досліду, де вирощували сорт Дарунок Степу цей показник був на 7,9\% нижчий і становив 20,2 тис. грн/га. Найменш прибутковими виявилися вирощування сортів Оплот (14,3 тис. грн/га) і Світ $(15,1$ тис. грн/га), якщо порівнювати з найкращим сортом (Царевич), то відбулося зниження цього показника на $52,4 \%$ та 44,3\%, відповідно. Зазначимо, що, в середньому по фрактору, сорт Отаман забезпечив одержання умовного чистого прибутку на рівні 17,2 тис. грн/га, що на 26,7\% менше, ніж за вирощування високопродуктивного сорту Царевич.

Застосування інокуляції насіння (фактор В) сприяло сталому зростанню умовного чистого прибутку вирощування гороху посівного. Слід відзначити, що ефективність застосування їх визначалася в першу чергу сортовим складом досліджуваної культури.

Максимальний вплив сортового складу продемонстровано на прикладі сорту Світ, оскільки умовний чистий прибуток сягнув позначки в 17,3 тис. грн/га лише за умови застосування інокулянта Біогель. Натомість препарат АКМ найкраще спрацював у варіанті 3 copтами Оплот і Царевич.

Застосування хімічного захисту рослин найбільшою мірою вплинуло на фрормування умовного чистого при-

Таблиця 1 - Умовний чистий прибуток при вирощуванні насіння гороху посівного залежно від сортового складу, інокуляції насіння та захисту рослин, тис. грн/га (середнє за 2018-2020 рр.)

\begin{tabular}{|c|c|c|c|c|c|c|}
\hline \multirow{2}{*}{$\begin{array}{c}\text { Сорт } \\
\text { (фактор A) }\end{array}$} & \multirow{2}{*}{ Інокулянт (фрактор В) } & \multicolumn{3}{|c|}{ Захист рослин (фактор С) } & \multicolumn{2}{|c|}{ Середнє по } \\
\hline & & без захисту & біоло-гічний & хімічний & B & A \\
\hline \multirow{3}{*}{ Дарунок Степу } & Контроль (вода) & 12,2 & 18,8 & 21,7 & 17,6 & \multirow{3}{*}{20,2} \\
\hline & AKM & 14,4 & 23,7 & 24,5 & 20,8 & \\
\hline & Біогель & 15,4 & 24,6 & 26,6 & 22,2 & \\
\hline \multirow{3}{*}{ Світ } & Контроль (вода) & 8,8 & 13,3 & 16,2 & 12,8 & \multirow{3}{*}{15,1} \\
\hline & AKM & 10,4 & 16,4 & 19,0 & 15,3 & \\
\hline & Біогель & 12,7 & 19,3 & 19,9 & 17,3 & \\
\hline \multirow{3}{*}{ Оплот } & Контроль (вода) & 9,1 & 12,3 & 14,6 & 12,0 & \multirow{3}{*}{14,3} \\
\hline & AKM & 10,7 & 16,8 & 17,5 & 15,0 & \\
\hline & Біогель & 11,5 & 17,6 & 18,6 & 15,9 & \\
\hline \multirow{3}{*}{ Отаман } & Контроль (вода) & 10,4 & 14,5 & 19,3 & 14,7 & \multirow{3}{*}{17,2} \\
\hline & AKM & 12,7 & 19,0 & 21,5 & 17,7 & \\
\hline & Біогель & 14,5 & 20,4 & 22,4 & 19,1 & \\
\hline \multirow{3}{*}{ Царевич } & Контроль (вода) & 15,1 & 19,9 & 21,9 & 19,0 & \multirow{3}{*}{21,8} \\
\hline & AKM & 17,4 & 25,5 & 25,1 & 22,7 & \\
\hline & Біогель & 17,4 & 26,8 & 27,2 & 23,8 & \\
\hline \multicolumn{2}{|c|}{ Середнє за фрактором C } & 12,8 & 19,3 & 21,1 & & \\
\hline
\end{tabular}


бутку - проявилось його збільшення до 21,1 тис. грн/га або на $64,8 \%$, якщо порівнювати з середніми значеннями контрольного варіанту.

Зауважимо, що система біологічного захисту також проявила високу активність порівняно з контрольним варіантом і обумовило зростання цього показника на $50,8 \%$. І цей результат, з огляду на чинник одержання екологічно чистої продукції, можна вважаємо цілком успішним і придатним для використання у виробництві.

Рівень рентабельності при вирощуванні насіння гороху посівного також був значною мірою пов'язаний з набором різних за насіннєвою продуктивністю сортів, які були включені до схеми польового досліду. Найрентабельнішим виявилися сорти Царевич і Дарунок Степу, забезпечивши результат на рівні 163,9 і 153,4\%, відповідно.

Встановлено, що за рахунок близьких показників витрат та низької врожайності насіння, а відповідно й умовного чистого прибутку, вирощування сортів гороху Оплот і Світ характеризується меншою рентабельністю - відповідно 116,5 та 110,6\%, що пов'язано з меншим рівнем адаптивності даних сортів до посушливих умов Південного Степу. Натомість продукції Отаман притаманна середня рентабельність, а саме - 131,4\%.

Зауважимо, що за використання інокулянту АКМ досліджуваний показник збільшилося на 18,6\%. Сорт Оплот мав найменший рівень рентабельності у дослідженні за відмови від інокуляції (контроль - обробка насіння перед сівбою чистою водою), а саме - 99,2\%. Сорт гороху Царевич, в аналогічній конфрігурації досліджуваних варіантів мав рентабельність на рівні 143,7\%, і збільшується до 178,1\% (на 34,4\%) за рахунок використання препарату Біогель.

Якщо проаналізувати вплив захисту рослин (фактор С) на рівень рентабельності, то можна дійти висновку, що найнижчим цей показник виявився у контрольному варіанті (без захисту рослин - обробка посівів водою). При цьому, в середньому по фрактору, рентабельність склала 104,4\%. Біологічний захист рослин дозволив підвищити досліджуваний показник до 147,2\%, проте максимальним він був за хімічного захисту - 153,8\%.

Найвищий рівень надходження енергії, у середньому за роки проведення досліджень (2018-2020рр.) та в середньому по фрактору А, був відзначений за вирощування сортів Царевич (46,0 ГДж/га) і Дарунок Степу (43,7 ГДж/га). Мінімальне значення даного енергетичного показника з одиниці посівної площі в польовому досліді гектара зафіксовано у сортів Оплот (35,6 ГДж/га) та Світ (36,7 ГДж/га). Вирощування насіння гороху посівного сорту Отаман забезпечило надходження енергії на рівні 39,6 ГДж/га, що на 16,16\% менше, ніж у найкращому варіанті з сортом Царевич. Але якщо порівнювати вищеназваний сорт з сортом Оплотом, то різниця між ними склала $29,2 \%$.

Інокуляції насіння перед сівбою (фрактор В) була найефективнішою у взаємодії з найпродуктивнішими сортами - Дарунок Степу й Царевич. Значущіша різниця проявилась між варіантами як з інокуляцією, так і без неї. Зауважимо, що за вирощування гороху сорту Дарунок Степу надходження енергії, у середньому по фактору, збільшилося 3 40,1 до 46,4 ГДж/га у варіанті з препаратом Біогель - ця різниця склала 15,7\%. Ця тенденція зберігається й у випадку з іншими сортами.

По третьому фрактору - захист рослин (фактор С), проявилась перевага застосування хімічного захисту рослин, який забезпечив найбільше надходження енергії з одного гектара посівної площі при вирощування насіння гороху посівного. У порівнянні з середніми значеннями в групі контролю (33,0 ГДж/га) цей енергетичний показник підвищився до 45,6 ГДж/га, або на 27,63\%. Слід відзначити, що біологічний захист рослин також сприяв формуванню більш високого надходження енергії $з 1$ га насіннєвих посівів.

Витрати енергії на технологію вирощування насіння гороху посівного змінювались меншою мірою, що можна пояснити особливістю схеми досліду. Сортовий склад майже не впливав на формування цього показника, коливаючись у межах від 19,5 ГДж/га (сорти Світ, Оплот) до 20,2 ГДж/га (сорт Царевич).

Вплив хімічного та біологічного захисту на енергетичні витрати на технологію вирощування насіння досліджуваної культур також був незначним. Про це насамперед свідчить результат, отриманий у контрольному варіанті фрактору C, а саме - 19,1 ГДж/га. Розрахунками доведено, що приріст енергії при вирощуванні насіння гороху посівного перш за все був обумовлений сортовим складом (табл. 2). Якщо за вирощування сортів Оплот і Світ, у середньому, сформувався приріст енергії на рівні 16,1 і 17,2 ГДж/га, відповідно, то у варіантах з сортами Царевич (25,8 ГДж/га) і Дарунок Степу (23,8 ГДж/га) це значення суттєво зросло. Різниця крайових значень було дуже суттєвим - 60,2\%. Сорт Отаман забезпечив формування досліджуваного енергетичного показника на рівні 19,9 ГДж/га, що на 29,64\% менше, ніж за вирощування сорту Царевич.

Інокуляція насіння гороху перед сівбою (фактор В) була ефективною як для низькопродуктивних, так і високоврожайних сортів. При цьому відзначились сорти Світ і Оплот. Якщо порівнювати з контрольним варіантом, то показник приросту енергії збільшився на 30,9\% у варіанті з інокулянтом Біогель та 19,8\% - на ділянках, де використовували препарат АКМ, відповідно. Наголосимо, що ця тенденція зберігається й для сортів з високим потенціалом врожайності, зокрема у варіанті з сортом Царевич приріст склав 13,6\% (Біогель), а для сорту Дарунок Степу з використанням цього ж інокулянту $-14,3 \%$. За вирощування без захисту рослин (контроль з обробкою вродою) приріст енергії, у середньому, склав 13,9 ГДж/га, то за умовах використання біологічної системи захисту рослин даний показник збільшився до 22,4 ГДж/га, або на 61,5\%.

Коефіцієнт енергетичної ефрективності був найвищим у сортів з високим потенціалом урожайності насіння. Це насамперед сорти Царевич $(2,28)$ і Дарунок Степу $(2,18)$. Інокуляція насіння перед сівбою препаратом АКМ виявилася ефективнішою, ніж використання Біогелю.

Застосування захисту рослин (фактор С) сприяло збільшенню коефіцієнту енергетичної ефективності за вирощування всіх сортів, насіннєва продуктивність яких вивчалась. Якщо у контрольному варіанті (обробка 
Таблиця 2 - Приріст енергії при вирощуванні насіння гороху посівного залежно від сортового складу, інокуляції насіння перед сівбою та захисту рослин, ГДж/га (середнє за 2018-2020 рр.)

\begin{tabular}{|c|c|c|c|c|c|c|}
\hline \multirow{2}{*}{$\begin{array}{c}\text { Сорт } \\
\text { (фактор A) }\end{array}$} & \multirow{2}{*}{ Інокулянт (фактор В) } & \multicolumn{3}{|c|}{ Захист рослин (фактор С) } & \multicolumn{2}{|c|}{ Середнє по } \\
\hline & & без захисту & біоло-гічний & хімічний & B & A \\
\hline \multirow{3}{*}{ Дарунок Степу } & Контроль (вода) & 14,3 & 23,0 & 27,4 & 21,6 & \multirow{3}{*}{23,8} \\
\hline & AKM & 15,9 & 28,2 & 29,9 & 24,7 & \\
\hline & Біогель & 16,0 & 28,1 & 31,4 & 25,2 & \\
\hline \multirow{3}{*}{ Світ } & Контроль (вода) & 9,7 & 15,7 & 20,1 & 15,2 & \multirow{3}{*}{17,2} \\
\hline & AKM & 10,8 & 18,7 & 22,7 & 17,4 & \\
\hline & Біогель & 12,7 & 21,4 & 22,8 & 19,0 & \\
\hline \multirow{3}{*}{ Оплот } & Контроль (вода) & 10,1 & 14,5 & 18,0 & 14,2 & \multirow{3}{*}{16,1} \\
\hline & AKM & 11,2 & 19,3 & 20,7 & 17,1 & \\
\hline & Біогель & 11,0 & 19,1 & 20,9 & 17,0 & \\
\hline \multirow{3}{*}{ Отаман } & Контроль (вода) & 11,9 & 17,3 & 24,2 & 17,8 & \multirow{3}{*}{19,8} \\
\hline & AKM & 13,8 & 22,1 & 26,1 & 20,6 & \\
\hline & Біогель & 14,9 & 22,8 & 26,0 & 21,3 & \\
\hline \multirow{3}{*}{ Царевич } & Контроль (вода) & 18,1 & 24,5 & 27,6 & 23,4 & \multirow{3}{*}{25,8} \\
\hline & AKM & 19,8 & 30,6 & 30,6 & 27,0 & \\
\hline & Біогель & 18,4 & 30,9 & 31,9 & 27,1 & \\
\hline \multicolumn{2}{|c|}{ Середнє за фрактором C } & 13,9 & 22,4 & 25,4 & & \\
\hline
\end{tabular}

водою) середній показник склав 1,73, то завдяки використанню біологічного захисту рослин його вдалося збільшити до 2,12, або на 22,5\%.

Енергоємність 1 тонни насіння гороху посівного певною мірою залежала від сортового складу досліджуваної культури. Найвищим цей показник був за вирощування сортів із низькою врожайністю, а саме - Оплот (11,7 ГДж) і Світ (11,4 ГДж). Мінімальний рівень енергоємності зафріксований у варіанті з сортом гороху Царевич (9,3 ГДж/т), дещо вище - за вирощування Дарунку Степу $(9,8$ ГДж/т) й Отаману $(10,6$ ГДж/т). Найбільше значення енергоємності 1 т насіння досліджуваної культури (10,8 ГДж) сформувалось за вирощування у варіанті без застосування інокулянтів (контроль). За використання біопрепарату АКМ даний енергетичний показник зменшився на 3,9\% - до 10,4 ГДж/т, а у варіанті з препаратом Біогель - 10,5 ГДж/т або на 2,1\%. Різниця між другим і третім варіантами була неістотною і склала 1,7\%. Високий рівень впливу в досліді стосовно формування енергоємності 1 тонни насіння досліджуваної культури, в середньому, 12,2 ГДж. Застосування біологічного захисту сприяло зменшенню цього енергопоказника на 2,2 ГДж/т або на 22,0\% порівняно з контрольним варіантом (обробка вродою). Хімічний захист був найоптимальнішим з точки зору витрат енергії на одиницю одержаної продукцію.

Висновки. Виробничі витрати мали тенденцію до зростання у сортів Отаман, Дарунок Степу та Царевич, а мінімальний показник - 12,8 тис. грн/га, отримано у варіанті з сортом Оплот. Використання інокулянтів не мало впливу на даний показник. За хімічного захисту одержали максимальний рівень виробничих витрат - 13,7 тис. грн/ га. Хімічний захист рослин сприяв одержанню найбільшого прибутку (21,1 тис. грн/га), що більше за контроль на $64,8 \%$. Біологічний захист також був високоефективним і перевищував контроль на 50,8\%. Максимальний рівень рентабельності вирощування насіння гороху, в середньому, 163,9 і 153,4\% забезпечили сорти Царевич і Дарунок Степу. Використання інокулянтів АКМ і Біогель сприяло зростанню цього показника на 18,633,3\%. Приріст сягнув максимальних значень, у середньому, 23,8 і 25,8 ГДж/га за вирощування сортів Дарунок Степу та Царевич. Коефріцієнт енергетичної ефективності мав максимальних значень 2,18-2,28 за вирощування сортів Дарунок Степу й Царевич.

\section{СПИСОК ВИКОРИСТАНОЇ ЛІТЕРАТУРИ:}

1. Бабич А. А. Світові земельні, продовольчі і кормові ресурси. Київ: Аграрна наука, 1996. 570 с.

2. Лимар А. О., Лимар В. А., Коковіхін С. В., Домарацький Є. О. Агрокліматичні ресурси півдня України та їх раціональне використання: монографія. Херсон: Грінь Д.С., 2015. 246 с.

3. Капінос М.В. Агроекономічна та енергетична оцінка елементів технології вирощування сортів гороху в умовах Південного Степу України. Зрошуване землеробство: міжвід. темат. наук. зб. Херсон: ОЛДІПЛЮС, 2019. Вип. 72. С. 135-138.

4. Лавриненко Ю. О., Коковіхін С. В., Ларченко О.В., Влащук А. М. Економічна оцінка елементів технології вирощування пшениці в умовах південного Степу України. Таврійський науковий вісник. 2009. Вип. 68.С. 12-20.

5. Ушкаренко В. О., Вожегова Р. А., Голобородько С. П., Коковіхін С. В. Методика польового досліду (зрошуване землеробство) : навчальний посібник. Херсон : Грінь Д. С., 2014. 448 с.

6. Методика определения экономической эффрективности использования в сельском хозяйстве результатов научно-исследовательских и опытно-конструкторских работ, новой техники, изобретений и рационализаторских предложений. Киев: Урожай, 1986. 117 c.

7. Медведовський О. К., Іваненко П. І. Енергетичний аналіз інтенсивних технологій в сільськогосподарському виробництві. Київ: Урожай, 1988. 205 с 


\section{REFERENCES:}

1. Babych, A.A. (1996). Svitovi zemelni, prodovolchi $i$ kormovi resursy [World land, food and feed resources]. Kyiv: Agrarian Science [in Ukrainian].

2. Lymar A. O., Lymar V. A., Kokovikhin S. V., Domarats'kyy Ye. O. (2015) Ahroklimatychni resursy pivdnya Ukrayiny ta yikh ratsional'ne vykorystannya [Agroclimatic resources of the south of Ukraine and their rational use]. Kherson: Grin D.S. [in Ukrainian].

3. Kapinos, M.V. (2019).Ahroekonomichnata enerhetychna otsinka elementiv tekhnolohiyi vyroshchuvannya sortiv horokhu v umovakh Pivdennoho Stepu Ukrayiny [Agroeconomic and energy assessment of elements of pea cultivation technology in the conditions of the Southern Steppe of Ukraine]. Irrigated agriculture, 72, 135-138 [in Ukrainian].

4. Lavrynenko, Yu.O., Kokovikhin, S.V., Larchenko, O.V., \& Vlashchuk, A.M. (2009). Ekonomichna otsinka elementiv tekhnolohiyi vyroshchuvannya pshenytsi v umovakh pivdennoho Stepu Ukrayiny [Economic evaluation of elements of wheat cultivation technology in the conditions of the southern steppe of Ukraine] Taurian Scientific Journal: Scientific Collection, 68, 12-20 [in Ukrainian].

5. Ushkarenko, V.O., Vozhegova, R.A., Goloborodko, S.P. \& Kokovikhin, S.V. (2014). Metodyka polyovoho doslidu (zroshuvane zemlerobstvo) [Methods of field experiment (irrigated agriculture)]. Kherson: Grin D.S. [in Ukrainian].

6. Metodyka opredelenyya ékonomycheskoy éffektyvnosty yspol'zovanyya $v$ sel'skom khozyaystve rezul'tatov nauchno-yssledovatel'skykh y opytnokonstruktorskykh rabot, novoy tekhnyky, yzobretenyy y ratsyonalyzatorskykh predlozheniy (1986). [Methods for determining the economic efficiency of the use in agriculture of the results of research and development, new equipment, inventions and innovation proposals]. Kyiv: Harvest [in Russian].

7. Medvedovsky, O.K. \& Ivanenko, P.I. (1988). [Energy analysis of intensive technologies in agricultural production]. Kyiv: Urozhay [in Ukrainian].

Вожегова Р. А., Сорокунський С. С. Економічна та енергетична ефективність вирощування насіння гороху посівного залежно від сортового складу, інокулянтів та захисту рослин

Мета - визначити економічну та енергетичну ефективність вирощування насіння гороху посівного залежно від сортового складу, інокулянтів та захисту рослин у неполивних умовах Південного Степу України. Методи. Польовий, економічний, енергетичний. Результати. Встановлено, що вартість валової продукції при вирощуванні насіння гороху посівного зросла до 33,3 тис. грн/ га у сорту Дарунок Степу, а на інших сортах зафіксували іï зменшення, в середньому, на 5,1-24,6\%. Собівартість виробництва насіння досліджуваної культури максимального рівня набула у сорту Світ - 7,5 тис. грн/т. У варіанті без захисту рослин зафіксували зростання цього показника, а за хімічного захисту він збільшився на 23,4\%, а за біологічного - на 19,7\%. Умовний чистий прибуток найбільшого рівня сягнув у варіанті з сортом Царевич, де він склав, у середньому, 21,8 тис. грн/га. а у сортів Оплот та Світ він істотно зменшився на 44,3-52,4\%. Біологічний захист рослин обумовив зростання рентабельності до $147,2 \%$, а хімічного - до $153,8 \%$. Мінімальне надходження енергії з врожаєм насіння гороху посівного було у сортів Оплот (35,6 ГДж/га) та Світ (36,7 ГДж/га). Застосування біологічної системи захисту сприяло істотному зростанню даного показник, у середньому, на 61,5\%, а за хімічного - на 82,7\%. Висновки. Виробничі витрати мали тенденцію до зростання у сортів Отаман, Дарунок Степу та Царевич, а мінімальний показник - 12,8 тис. грн/ га, отримано у варіанті з сортом Оплот. Використання інокулянтів не мало впливу на даний показник. За хімічного захисту одержали максимальний рівень виробничих витрат - 13,7 тис. грн/га. Хімічний захист рослин сприяв одержанню найбільшого прибутку (21,1 тис. грн/ га), що більше за контроль на 64,8\%. Біологічний захист також був високоефективним і перевищував контроль на 50,8\%. Максимальний рівень рентабельності вирощування насіння гороху, в середньому, 163,9 і 153,4\% забезпечили сорти Царевич і Дарунок Степу. Використання інокулянтів АКМ і Біогель сприяло зростанню цього показника на 18,6-33,3\%. Приріст сягнув максимальних значень, у середньому, 23,8 і 25,8 ГДж/га за вирощування сортів Дарунок Степу та Царевич. Коефіцієнт енергетичної ефрективності мав максимальних значень 2,18-2,28 за вирощування сортів Дарунок Степу й Царевич.

Ключові слова: горох посівний, насіння, сорт, інокулянт, захист рослин, економічна ефективність, енергетична оцінка.

Vozhehova R. A., Sorokunsky S. S. Economic and energy efficiency of growing pea seeds depending on varietal composition, inoculants and plant protection

Goal. The aim is to determine the economic and energy efficiency of growing pea seeds depending on the varietal composition, inoculants and plant protection in non-irrigated conditions of the Southern Steppe of Ukraine. Methods. Field, economic, energy. Results. It was established that the value of gross output when growing pea seeds increased to 33.3 thousand $\mathrm{UAH} /$ ha in the variety Darunok Stepu, and in other varieties its decrease was recorded, on average, by $5.1-24.6 \%$. The cost of production of seeds of the studied crop reached the maximum level in the variety Svit - 7.5 thousand $\mathrm{UAH} / \mathrm{t}$. In the variant without plant protection, an increase in this indicator was recorded, and in the case of chemical protection it increased by $23.4 \%$, and in the case of biological protection - by $19.7 \%$. The conditional net profit of the highest level reached in the variant with the variety Tsarevich, where it amounted to an average of 21.8 thousand $\mathrm{UAH} / \mathrm{ha}$. and in the varieties Oplot and Svit it significantly decreased by $44.3-52.4 \%$. Biological protection of plants led to an increase in profitability to $147.2 \%$, and chemical - to $153.8 \%$. The minimum energy yield with pea seed yield was in the varieties Oplot (35.6 GJ/ha) and Svit (36.7 GJ/ ha). The use of biological protection system contributed to a significant increase in this indicator, on average, by $61.5 \%$, and chemical - by $82.7 \%$. Conclusions. Production costs tended to increase in the varieties Otaman, Darunok Stepu and Tsarevich, and the minimum rate -12.8 thousand $\mathrm{UAH} /$ ha, obtained in the version with the variety Oplot. The use of inoculants had no effect on this indicator. For chemical protection received the maximum level of production costs - 13.7 thousand $\mathrm{UAH} / \mathrm{ha}$. Chemical plant protection 
contributed to the highest profit (21.1 thousand $U A H / h a)$, which is $64.8 \%$ more than the control. Biological protection was also highly effective and exceeded control by $50.8 \%$. The maximum level of profitability of pea seed cultivation, on average, 163.9 and $153.4 \%$ was provided by the varieties Tsarevich and Darunok Stepu. The use of inoculants AKM and Biogel contributed to the growth of this indicator by
18.6-33.3\%. The increase reached the maximum values, on average, 23.8 and $25.8 \mathrm{GJ} / \mathrm{ha}$ for the cultivation of Darunok Stepu and Tsarevich varieties. The coefficient of energy efficiency had maximum values of 2.18-2.28 for the cultivation of varieties Darunok Stepu and Tsarevich.

Key words: peas, seeds, variety, inoculant, plant protection, economic efficiency, energy assessment. 